\title{
Brownfield sites turned green: realising sustainability in urban revival
}

\author{
K. J. Doick, G. Sellers, T. R. Hutchings \& A. J. Moffat \\ Land Regeneration and Urban Greening Group, Forest Research, UK
}

\begin{abstract}
Greenspaces in the urban environment are widely recognised for their importance in the creation of healthy and sustainable communities. Greenspace establishment on reclaimed brownfield land is an important mechanism for reviving the urban environment. However, greenspace establishment impacts not only social but also environmental, ecological, economical and cultural dimensions. The identification of successes and failures within brownfield regeneration, through qualitative and quantitative evaluation, is paramount for demonstrating whether projects have attained their primary objectives, offer value for money and are sustainable. Currently, tools available for such evaluation fail to evaluate the true plethora of impacts of greenspace establishment and, hence, sustainability. This paper summarises over 110 identified impacts which could be used as evaluation criteria. The development and implementation of a toolbox based on the evaluation criteria is discussed, that would offer a means of determining monitoring needs on a site by site basis and a viable means of evaluating local or national impacts for a variety of urban greenspaces. The final product would provide a defensible mechanism by which redevelopments could be shown to have succeeded, according to a composite of individual functional aspirations and impacts. The lessons learnt through implementation of our toolbox would benefit future projects, enable Best Practice to be demonstrated and improved upon, and identify areas where benefits are not being fully realised.

Keywords: brownfields, urban regeneration, greenspaces, impacts, monitoring, evaluation, toolbox, social, environmental.
\end{abstract}




\section{Introduction}

From as early as the second half of the $19^{\text {th }}$ century, the provision of urban greenspaces in the form of municipal city parks has been seen as a means to alleviate the unhealthy attributes of city dwellers and factory workers NicholsonLord [1]. The open areas for physical exercise provided the additional benefit of being a place to socialise with friends and escape from the mental, as well as physical, confines of the work environment. Today, we have a much greater recognition of the benefits that urban greenspaces can offer and a realisation that they are not solely anthropomorphic (social, cultural, economic, planning, landscape) but also encompass environmental and ecological dimensions. The diverse range of benefits that urban greenspaces present is recognised in a UK government primary objective to "create safe and healthy local environments with well-designed public greenspace through a programme of brownfield land regeneration and community woodland establishment in the urban environment" ODPM [2]. Inherent in this objective is the consideration that brownfield redevelopment is de facto sustainable and, as such, has been presented as a UK government headline sustainability indicator DETR [3].

The drive for sustainable urban revival through brownfield redevelopment is not, however, solely in recognition of the benefits that urban greenspaces offer, but is a consequence also of economic pressures, demands for new housing and planning guidelines aimed at preventing urban sprawl. However, sustainability is not only about reducing consumption of raw materials or the reclamation of brownfield land as a sustainable alternative to developing virgin greenfield sites. Sustainability is an interplay between social, environmental, economic, cultural and ecological dimensions, over the long-term. Assessment of the sustainability of brownfield regeneration to urban greenspaces therefore requires sufficient evaluation of the impacts of the redevelopment and holistic interpretation of the interplay at work.

Examples of monitoring strategies currently available that can be used in the assessment of an urban greenspace establishment project, or in the design of an assessment package for such a project include the Redevelopment Assessment Framework (RAF) [4], A Guide to Monitoring and Evaluation [5], and Prove it! [6]. These packages only partially fulfil the monitoring specifications required to appraise the sustainability of an urban greenspace regeneration project. This is because each addresses only a limited number of evaluation criteria in their assessments. For example, RAF considers stakeholder interests but does not evaluate the regional economic implications of the redevelopment, whilst methodologies such as the UK government's Green Book (which is an approach to the evaluation of public sector expenditure on activities aimed at providing benefits to society [7]) do not consider wider environmental aspects, such as changes in ecological status.

This paper summaries results of a literature review that identified over 110 impacts of establishing greenspaces in the urban environment, which could be used to formulate evaluation criteria for the assessment of project sustainability. The development and implementation of a toolbox based on the evaluation 
criteria, together with stakeholder analysis, is discussed, that would allow monitoring needs to be determined on a site-by-site basis. Evaluation of the monitoring data would also offer a viable means of understanding local, regional and national impacts of brownfield regeneration-greenspace establishment projects. Employable at a range of greenspace types, from recreational playing fields to community woodlands, the toolbox would provide a defensible mechanism by which redevelopments could be shown to have succeeded, according to a composite of individual functional aspirations and impacts. The lessons learnt through implementation of our toolbox would provide the evidence base to support and benefit future projects, enable Best Practice to be targeted, demonstrated and improved, and identify areas where benefits are not being fully realised.

\section{Impacts of establishing urban greenspaces}

\subsection{Defining the impacts of establishing urban greenspaces}

Table 1 summaries an extensive literature review into the impacts associated with greenspace establishment in the urban environment. The review identified over 110 impacts related to social, environmental, ecological, engineering, economical and cultural aspects of urban greenspace regeneration.

Table 1: $\quad$ Impacts of establishing urban greenspace on brownfield land.

\begin{tabular}{|c|c|c|}
\hline Generic Impact & Details & Summary of Evidence \\
\hline Social & $\begin{array}{l}\text { General public visits } \\
\text { Sports and recreational facilities } \\
\text { Human health, health and safety } \\
\text { Access, sense of ownership } \\
\text { Social inclusion (array of social } \\
\text { classes using site, evidence of social } \\
\text { exclusions) } \\
\text { Educational resource } \\
\text { Fear (real, perceived) }\end{array}$ & $\begin{array}{l}\text { Numbers of: } \\
\text { Formal visits (social activities/ events) } \\
\text { Informal visits (passive enjoyment; } \\
\text { walking the dog, socialising) } \\
\text { Increase in personal / public health } \\
\text { and well-being (active enjoyment, } \\
\text { mental well-being and release) } \\
\text { Extent of open public access } \\
\text { Too many/too few people around }\end{array}$ \\
\hline Urban impacts & $\begin{array}{l}\text { Urban heat island effects (ambient } \\
\text { temperature, cooling due to } \\
\text { evapotranspiration and shading); } \\
\text { Meteorology } \\
\text { Noise abatement } \\
\text { Aesthetic appeal of city/urban } \\
\text { environment } \\
\text { Visual screening of urban structures }\end{array}$ & $\begin{array}{l}\text { Impacts on people's thermal comfort } \\
\text { Atmospheric pollution formation } \\
\text { cycles } \\
\text { Economics in relation to heating and } \\
\text { air conditioning bills } \\
{[8-10]}\end{array}$ \\
\hline $\begin{array}{l}\text { Air quality (air } \\
\text { pollution) }\end{array}$ & $\begin{array}{l}\text { Particulates }\left(\mathrm{PM}_{10} \text { and } \mathrm{PM}_{2.5}\right) \\
\text { Heavy metals and potentially toxic } \\
\text { elements } \\
\text { NOx and SOx, Ozone } \\
\text { Biogenic and anthropogenic } \\
\text { hydrocarbons, persistent organic } \\
\text { pollutants, volatilization of bitumen } \\
\text { Air temperature }\end{array}$ & $\begin{array}{l}\text { Trapping and uptake of atmospheric } \\
\text { pollutants by vegetation } \\
\text { VOCs emitted as well as trapped by } \\
\text { vegetation } \\
{[11,12]}\end{array}$ \\
\hline
\end{tabular}


Table 1 Continued.

\begin{tabular}{|c|c|c|}
\hline Generic Impact & Details & Summary of Evidence \\
\hline $\begin{array}{l}\text { Soil and ground } \\
\text { contamination } \\
\text { issues }\end{array}$ & $\begin{array}{l}\text { Compartmentation of contaminants in } \\
\text { soil and vegetation } \\
\text { Potential of food chain transfer } \\
\text { Exposure to human visitors } \\
\text { Effects of re-vegetating on } \\
\text { contaminant stability } \\
\text { Erosion extent and impact }\end{array}$ & $\begin{array}{l}\text { Contaminant uptake by plants leading } \\
\text { to food chain transfer } \\
\text { Sub-standard vegetation establishment } \\
\text { due to contaminants and low quality } \\
\text { status of soil } \\
\text { Penetrate of landfill caps by tree roots } \\
{[13,14]}\end{array}$ \\
\hline $\begin{array}{l}\text { Water supply, } \\
\text { management, } \\
\text { quality and } \\
\text { chemistry }\end{array}$ & $\begin{array}{l}\text { Rainfall interception and infiltration } \\
\text { Surface water quality (pH, BOD, } \\
\text { nitrate, suspended solids, turbidity) } \\
\text { Invertebrate biology } \\
\text { Water reserves (site and region) } \\
\text { Flood risk and management }\end{array}$ & $\begin{array}{l}\text { Infiltration rates influence catchment } \\
\text { yields, on-site and off-site flooding } \\
\text { potential } \\
\text { Soil runoff affects water quality and } \\
\text { loading } \\
{[13,15]}\end{array}$ \\
\hline Soil quantity/quality & $\begin{array}{l}\text { Soil chemistry (organic matter, } \\
\text { soil carbon, NPK, pH, CEC) } \\
\text { Biology (invertebrate diversity and } \\
\text { numbers) } \\
\text { Physical (density, temperature) }\end{array}$ & $\begin{array}{l}\text { Low quality soil resource, low organic } \\
\text { matter content, poor nutrient status, } \\
\text { minimal faunal populations } \\
\text { temporal changes post regeneration } \\
\text { Vegetation reduces soil erosion. }\end{array}$ \\
\hline $\begin{array}{l}\text { Biodiversity and } \\
\text { conservation value }\end{array}$ & $\begin{array}{l}\text { Tree (health, vigour, damage, stand } \\
\text { management, weed control) } \\
\text { Flora (habitats, species composition, } \\
\text { diversity, performance) } \\
\text { Fauna (invertebrate through to reptile } \\
\text { and mammal) }\end{array}$ & $\begin{array}{l}\text { Low quality soil resource affects tree } \\
\text { and vegetation establishment } \\
\text { Temporal changes in soil flora and } \\
\text { fauna, aquatic and total biodiversity } \\
\text { [15-17] }\end{array}$ \\
\hline Habitat creation & $\begin{array}{l}\text { New and native woodland creation, } \\
\text { wetlands, wildflower meadows and } \\
\text { parklands } \\
\text { Natural regeneration }\end{array}$ & $\begin{array}{l}\text { Site sustainability affected by site } \\
\text { capacity to self regenerate } \\
\text { National sustainability measured by } \\
\text { coverage of native habitats }\end{array}$ \\
\hline Engineering aspects & $\begin{array}{l}\text { Soil compaction, water-logging } \\
\text { Landfill tip stability } \\
\text { Engineering structures functionality } \\
\text { (e.g. berms, drains and culverts) } \\
\text { Road/path condition (fitness for } \\
\text { purpose) } \\
\text { Evidence of leachate breakout }\end{array}$ & $\begin{array}{l}\text { Compaction limits rainfall infiltration } \\
\text { and vegetation establishment } \\
\text { Durability (wear and tear as well as } \\
\text { vandalism) of sub surface and on site } \\
\text { engineering structures indicative of } \\
\text { sustainability and long term } \\
\text { maintenance requirement of site }\end{array}$ \\
\hline Site condition & $\begin{array}{l}\text { Aesthetic appeal } \\
\text { Landscape value } \\
\text { Littering and vandalism } \\
\text { Nuisance (motor bikes) }\end{array}$ & $\begin{array}{l}\text { Aesthetic appeal influences site usage } \\
\text { through to desirability of } \\
\text { neighborhood and local house prices } \\
\text { Vandalism indicates financial burden } \\
\text { of site and sense of ownership by } \\
\text { local community }[18,19]\end{array}$ \\
\hline Economic & $\begin{array}{l}\text { Employment creation (recreation, } \\
\text { sport, tourism, site maintenance, } \\
\text { management, influx of new business) } \\
\text { Increased local prosperity (land value, } \\
\text { existence value, jobs) } \\
\text { Carbon sequestration } \\
\text { Non-marketable benefits (pollution } \\
\text { mitigation, personal health, amenity) }\end{array}$ & $\begin{array}{l}\text { Revenue income from users } \\
\text { Value of peripheral land and property } \\
\text { Trees and plants as a marketable } \\
\text { resource } \\
{[20-22]}\end{array}$ \\
\hline Cultural & $\begin{array}{l}\text { Cultural identity } \\
\text { Interaction, use by ethnic groups } \\
\text { Landscape value } \\
\text { Preservation of environmental/ } \\
\text { natural and cultural heritage, } \\
\text { historical heritage and archaeology }\end{array}$ & $\begin{array}{l}\text { Historical and industrial uses of a site } \\
\text { relate to local community, ranging } \\
\text { from proud of heritage to site as an } \\
\text { eyesore. Sense of ownership, } \\
\text { belonging and pride }[16,18-20]\end{array}$ \\
\hline
\end{tabular}




\subsection{Capturing the impacts of establishing urban greenspaces}

The impacts associated with urban greenspace establishment demonstrated in Table 1 are wide ranging. Some impacts are subtle (e.g. changes in the numbers of dog walkers visiting a site), whilst others are more dramatic (e.g. changes in aesthetic appeal of the site). Some occur immediately upon regeneration (e.g. availability of recreational space for the local communities), others may take years to decades to be fully realised (e.g. attitudes of local communities to the environment, or sense of ownership). Consequently, resource requirements to qualify or quantify these impacts vary considerably. For example, data collection can proceed in a variety of ways from site surveys by local interest groups (e.g. wildlife groups) through to interpretation of national databases. How then do we assure data quality and comparability over the evaluation period?

Quality assurance is imperative not only for ensuring that data is comparable between sites, but also to prove that decisions and conclusions for each individual site are fully accountable and auditable. Therefore a formal and structured quality management system (QMS) must be adopted. A QMS such as the UK's Joint Code of Practice for Research [23] requires an overarching deployment plan that unambiguously defines the project concept, a review of the literature and the main aims and objectives of the project. Standard operating procedures (SOPs) are subsequently produced, which enable any competent person to undertake monitoring (data collection) at any site in a manner that will generate data that is comparable (by virtue of the standardised data collection methodology) to other sites in the same regeneration programme as well as to unrelated and control sites. Furthermore, a data management system (DMS) is required, in support of the QMS, which offers a central secure location for data to be analysed following standard procedures for collation, manipulation, transformation and statistical analysis.

\section{Formulating a monitoring and evaluation strategy}

\subsection{Traditional ad hoc approaches}

Whether for one site or a regeneration programme consisting of multiple sites, assessment of the sustainability of the project can only occur through a truly holistic appraisal of the regeneration process and the impacts that ensue. There are several approaches that are potentially useful in deciding what criteria should be included in the monitoring and evaluation strategy, given that the range of impacts is so diverse. A traditional approach is to list the primary goals, outputs and aspirations for a site. Subsequently, monitoring is targeted directly and exclusively at those items on the list to demonstrate the successes and shortcomings of the project. Such an approach does little to capture the wider impacts of the project, or evaluate site sustainability post-regeneration. For example, the primary objectives of a regeneration project may be to provide public benefit through a variety of recreational facilities and improved local connectivity 
through the provision of new foot and cycle paths. If these objectives were the sole items for monitoring and evaluation, wider impacts such as increased site (local) biodiversity would not be captured.

An alternative approach to monitoring and evaluation is via interpretation of the data needs of the funding body or principal stakeholder(s); in other words, via stakeholder analysis. For example, regional development agencies in the UK have a specific role of promoting economic regeneration. Subsequently, a regeneration project would include primary objectives such as 'create employment opportunities', 'complement other regeneration activity' or 'make significant contributions to the delivery of the regional economic strategy'. A monitoring strategy devised to exclusively demonstrate the fulfilment of these objectives may offer insight into the numbers of new businesses set up in the region, the influx of skilled workers or changes in house prices in the vicinity of the project, but is unlikely to demonstrate environmental consequences such as changes in bird of prey or mammal numbers, atmospheric pollution abatement or the attitudes of local people to the site (e.g. using quality of life indices [24]). The assumption that regeneration is inherently sustainable development may prove to be flawed if monitoring results demonstrate negative externalities, lowvalue project returns or lower than expected returns for the capital investment, or if factors extraneous to the regeneration programme (e.g. a slump in house prices) mask any regional economic growth promoted by the greenspace development.

\subsection{An integrated and holistic approach to monitoring and evaluation}

Monitoring and evaluation strategies may encompass several of the primary objectives or goals for a regeneration project, the functions or roles expected to be fulfilled by the greenspace, site aspirations or project outputs. To be useful, monitoring the sustainability of a regeneration project needs to be via a strategy bespoke to each site, but how does one have a bespoke design yet still maintain data comparability across sites in a rigorous QA system? A review of urban greenspace establishment programmes and of the literature has shown that there is significant and relevant overlap between the objectives of different regeneration projects; equally, stakeholder interests are very similar between the projects. Furthermore, greenspaces fulfil often similar functions for local communities, and similar impacts of regeneration can be identified even between dissimilar locations and sites. It is the recognition of these overlaps, and the ability to rank and sort potential criteria for monitoring that enables a strategy to be designed that meets approval by the funding bodies and is capable of evaluating site sustainability.

Figure 1 presents a flow diagram demonstrating the process that should be followed in order to select a balanced list of evaluation criteria for a regeneration project; monitoring indicators are subsequently selected from the toolbox to satisfy the identified evaluation criteria. The first step involves identification of stakeholders, project aims and objectives, functions and impacts. Stakeholders are identified from a checklist within the toolbox, which includes inter alia statutory and non-statutory bodies, local interest groups and local communities, 
public bodies and funding bodies. The conversion of stakeholder views, aims, aspirations, concerns and interests into relevant evaluation criteria is undertaken via a sequence of workshops, wherein stakeholders state, discuss and then collectively agree their principal criteria for evaluation. An example of how this process may be undertaken is given by Pediaditi et al. [4].

Project aims and objectives are identified from the project outline, proposal or funding application. Functional aspirations are revealed through public consultations documentation (surveys and minutes of meetings), predevelopment ecological site surveys, desktop studies and site walkover reports. Finally, the impacts of a greenspace establishment programme are assessed via the toolbox. Site factors such as history and location play an important role in the selection of probable impacts of the project that should be considered. However, a range of impacts from the toolbox, relating to all the dimensions (social, environmental, ecological, economical and cultural, as well as local, national and regional impacts), should be selected to ensure an integrated approach to monitoring and the potential to identify unexpected impacts. In this way, the toolbox reflects the whole programme approach to monitoring advocated by European Directive 2001/42/EC 'on the assessment of the effects of certain plans and programmes on the environment' [25] and the integrated approach to Sustainability Appraisal endorsed by ODPM [26].

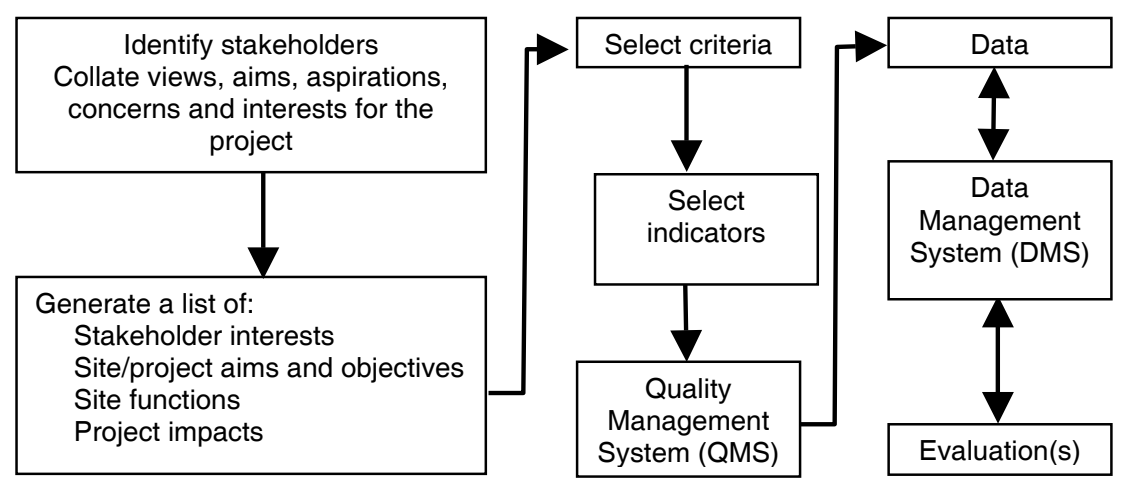

Figure 1: Selection of evaluation criteria and monitoring indicators based on stakeholder interests, site functions and impacts of urban greenspace.

For the toolbox, a QMS is proposed that is compliant with the UK's Joint Code of Practice [23]. Subsequently, the QMS would require an over-arching deployment plan that details the concept of the toolbox and its role and purpose. The QMS will also demonstrate how the over-arching deployment plan applies at local, regional and national scales, and how deployment plans should be drawn up for each new site. These plans will derive the evaluation criteria (i.e. impacts, 
aims, functions and stakeholder requirements) specific to the programme to be monitored and which indicators will be employed for each criterion. SOPs for data collection and handling will then be taken directly from the toolbox for use at each site to ensure that methodologies are consistently applied.

A concern when devising any monitoring and evaluation strategy is resource availability; inevitably financial constraints limit the number of monitoring indicators that can be assigned. It is therefore pertinent to stress that project aims and objectives are frequently the same or very similar to, for example, site functions or stakeholder data requirements - it is just that they are, invariably, listed separately. Similarly, many impacts of a project will also be intentional project functions, outputs or outcomes. Through systematic identification and, subsequently, detailing the aims and functions, etc., of a project, the maximum number of evaluation criteria can be identified and the optimum number for adoption can be defensibly agreed. Importantly, it is this initial, systematic approach that proves the maximum list and, therefore, ensures a holistic approach; in other words, important criteria are not omitted through oversight. The toolbox ensures that at least one indicator is selected per evaluation criterion and only fitness-for-purpose indicators are employed. Indicator suitability will be tested against parameters of inter alia specificity, responsiveness and natural variability, measurement error and longevity (Hunsaker [27]).

\section{Implications of the monitoring and evaluation toolbox}

The identification of successes and shortfalls in greenspace establishment projects, through qualitative and quantitative evaluation, is paramount for demonstrating whether projects have attained their primary objectives and delivered value for money. The need for such evaluation is recognised by Governments, yet the few disjointed tools that are currently available fail to evaluate the true plethora of impacts associated with either regeneration projects per se or the establishment of greenspace. The identification of the multitude of impacts of a regeneration project enables conclusions to be drawn from the evaluation process that provide a well balanced picture of the sustainability of the project. Undeniably required, the proposed toolbox discussed herein will provide a defensible mechanism by which redevelopment programmes can be shown to have succeeded. Bespoke monitoring and evaluation strategies, on a site or programme basis, will enable success to be measured according to a composite of individual functional aspirations, directly relevant to that site. Concurrently, the meticulous design of a bespoke monitoring strategy ensures that stakeholder demands for project feedback are satisfied and resources are targeted at areas most in need of monitoring. Additional benefits of a bespoke strategy include the ability to make accountable management decisions and map temporal changes in outputs, impacts or functions that are primary objectives for a site. Finally, by ensuring data are fully comparable between sites and through widespread application of the monitoring and evaluation strategies designed using our toolbox, lessons can be learnt to benefit future projects, enable Best 
Practice to be demonstrated and improved, and changes can be implemented where social, environmental or economical benefits are not being fully realised.

\section{References}

[1] Nicholson-Lord, D., The Greening of the Cities. London: Routledge and Kegan Paul, 1987.

[2] Office of the Deputy Prime Minister (ODPM), Sustainable communities: building for the future, ODPM London, 2003.

[3] Department of Environment, Transport and the Regions (DETR), A better quality of life: A strategy for sustainable development in the $U K, C m$ 4345, The Stationery Office, London, 1999.

[4] Pediaditi, K., Wehrmeyer, W. \& Chenoweth, J., Monitoring sustainability of brownfield redevelopment projects: the Redevelopment Assessment Framework. Land Contamination and Reclamation, 13(2): pp. 173-183, 2005.

[5] ECOTEC, Open Space and The Countryside Agency, A guide to monitoring and evaluation, The Countryside Agency: London, p. 24, 2004.

[6] New Economics Foundation, Prove it! Measuring the effect of neighbourhood renewal on local people, Groundwork, London: RAP, 2000.

[7] HM Treasury, Green Book: appraisal and evaluation in central government, The Stationery Office, London, 2003.

[8] Brack, C.L., Pollution mitigation and carbon sequestration by an urban forest. Environmental Pollution, 116(Supplement 1): pp. S195-S200, 2002.

[9] Akbari, H., Shade trees reduce building energy use and $\mathrm{CO}_{2}$ emissions from power plants. Environmental Pollution, 116(Supplement 1): pp. S119-S126, 2002.

[10] Fang, C.-F. \& Ling, D.-L., Guidance for noise reduction provided by tree belts. Landscape and Urban Planning, 71(1): pp. 29-34, 2005.

[11] Taha, H., Modeling impacts of increased urban vegetation on ozone air quality in the South Coast Air Basin. Atmospheric Environment, 30(20): pp. 3423-3430, 1996.

[12] Beckett, K.P., Freer-Smith, P.H. \& Taylor, G., Urban woodlands: their role in reducing the effects of particulate pollution. Environmental Pollution, 99(3): pp. 347, 1998.

[13] Hartanto, H., Prabhu, R., Widayat, A.S.E. \& Asdak, C., Factors affecting runoff and soil erosion: plot-level soil loss monitoring for assessing sustainability of forest management. Forest Ecology and Management, 180(1-3): pp. 361, 2003.

[14] Nowak, D.J., Crane, D.E., Walton, J.T., Twardus, D.B. \& Dwyer, J.F., Understanding and quantifying urban forest structure, functions, and value. Proc. of the 5th Canadian urban forest conference, eds. W.A. Kenney, J. McKay, and P. van Wassaneaers, Urban Forest Council: Markham, Ontario, Canada, 2002. 
[15] Freer-Smith, P.H. \& Read, D.B., The relationship between crown condition and soil solution chemistry in oak and Sitka spruce in England and Wales. Forest Ecology and Management, 79(3): pp. 185, 1995.

[16] Dunnett, N., Swanwick, C. \& Woolley, H., Improving Urban Parks, Play Areas and Open Spaces, ed. Department for Transport, Local Government and the Regions (DTLR), The Stationery Office, London, pp. 217, 2002.

[17] Biodiversity in Urban Habitat Patches: URGENT Annual Meeting 2000 Proceedings: Ecology Science Project Presentations; Angold, P., Hill, M., Rushton, S. \& Pullin, A., Online. http://urgent.nerc.ac.uk/Meetings/ 2000/2000Proc/ecology/angold.htm

[18] Nijkamp, P., Rodenburg, C.A. \& Wagtendonk, A.J., Success factors for sustainable urban brownfield development: a comparative case study approach to polluted sites. Special Section: Economics of Urban Sustainability. Ecological Economics, 40: pp. S235-S252, 2002.

[19] Kuo, F.E. \& Sullivan, W.C., Environment and crime in the inner city: does vegetation reduce crime? Environment and Behavior, 33(3): pp. 343-367, 1999.

[20] De Sousa, C.A., Turning brownfields into green space in the City of Toronto. Landscape and Urban Planning, 62(4): pp. 181, 2003.

[21] Gatrell, J.D. \& Jensen, R.R., Growth through greening: developing and assessing alternative economic development programmes. Applied Geography, 22(4): pp. 331, 2002.

[22] Thériault, M.K.Y. \& Des Rosiers, F., The impact of mature trees on house values and on residential location choices in Quebec City. Proc. of the. 1st biennial meeting of the International Environmental Modelling and Software Society, eds. Rizzoli, A.E. \& Jakeman A.J., University of Lugano, Switzerland, pp. 478-483, 2002.

[23] Department for Environment, Food and Rural Affairs (DEFRA), Joint Code of Practice for Research, 2003, Online. http://www.defra.gov.uk /science/documents/QACoP_V8.pdf

[24] Department for Environment, Food and Rural Affairs (DEFRA), Securing the Future - UK Government sustainable development strategy, The Stationery Office, London. pp. 186, 2005.

[25] European Commission, On the assessment of the effects of certain plans and programmes on the environment, The Strategic Environmental Assessment [SEA] Directive, 2001/42/EC, 2001.

[26] Office of the Deputy Prime Minister (ODPM), Sustainability appraisal of regional spatial strategies and local development frameworks, Consultation paper, 2004, Online. www.odpm.gov.uk/stellent/groups/ odpm_planning/documents/page/odpm plan_030923.pdf

[27] Hunsaker, C.T., New concepts in environmental monitoring: the question of indicators. The Science of the Total Environment Supplement, Part 1: pp. 77-95, 1993. 